Counsellia: Jurnal Bimbingan dan Konseling

Volume 11 (2) 157 - 167 November 2021

ISSN: 2088-3072 (Print) / 2477-5886 (Online)

DOI: $10.25273 /$ counsellia.v11i2.10390

Available online at: http://e-journal.unipma.ac.id/index.php/JBK

\title{
Layanan Penguasaan Konten Berbasis Digital Game Based Learning untuk Mengurangi Burnout Belajar
}

Anna Ayu Herawati ${ }^{1} \square$, Vira Afriyati ${ }^{2}$, Arsyadani Mishbahuddin ${ }^{3}$, Ahmad Syaf Ya

Habibi $^{4}$

${ }^{1,2,3}$ Fakultas Keguruan dan Ilmu Pendidikan, Universitas Bengkulu, Bengkulu

${ }^{4}$ Fakultas Ilmu Pendidikan, Universitas Negeri Padang, Sumatera Barat

email: $\square$ Annaayuherawati@unib.ac.id

email: Viraafriyati@unib.ac.id

email: Haidardani@ gmail.com

email: Habibidoang91@gmail.com

\begin{abstract}
Abstrak: Penelitian ini dilatar belakangi oleh masih ditemukan mahasiswa yang mengalami burnout belajar seperti gejala yang nampak menunda-nunda belajar, tidak memiliki semangat dalam belajar, terlihat jenuh dengan aktivitas belajar, merasa frustasi dengan tuntutan perkuliahan dan sebagainya. Penelitian ini bertujuan untuk mendeskripsikan efektivitas layanan penguasaan konten berbasis digital game based learning untuk mengurangi burnout belajar. Penelitian ini menggunakan metode kuantitatif. Jenis penelitian ini adalah Quasi Experiment dengan rancangan One Group Pretest- Posttest Design. Subjek penelitian ini adalah mahasiswa BK UNIB sebanyak 37 mahasiswa. Instrumen penelitian yang digunakan adalah skala burnout belajar dengan model Likert. Hasil penelitian ini diharapkan memiliki implikasi terhadap kegiatan belajar selanjutnya dan kemajuan program studi bimbingan dan konseling UNIB. Implikasi dari hasil penelitian ini yaitu dapat dijadikan sebagai bahan masukan dalam mengembangkan layanan bimbingan dan konseling yang lebih menarik sesuai kebutuhan, terutama dalam layanan penguasaan konten berbasis digital game based learning dengan aplikasi kahoot untuk mengurangi burnout belajar.
\end{abstract}

Kata kunci: Burnout Belajar, Penguasaan konten, Digital Game Based Learning

\begin{abstract}
Abstrack: This research is motivated by the fact that students still experience learning burnout such as symptoms that seem to procrastinate in learning, do not have enthusiasm in learning, look bored with learning activities, feel frustrated with the demands of lectures, and so on. This study aims to describe the effectiveness of digital game-based learning content mastery services to reduce learning burnout. This study uses quantitative methods. This type of research is a Quasi Experiment with One Group Pretest-Posttest Design. The subjects of this study were BK UNIB students as many as 37 students. The research instrument used was a learning burnout scale with a Likert model. The results of this study are expected to have implications for further learning activities and the progress of the UNIB guidance and counseling study program. The results of this study imply that it can be used as input in developing more attractive guidance and counseling services as needed, especially in content mastery services based on digital game-based learning with kahoot applications to reduce learning burnout.
\end{abstract}

Keywords : Learning Burnout; mastery of content; digital game based learning.

Received ; 26 -10-2021 Accepted ; 06-11-2021 Published; 29-11-2021 
Citation: Herawati, Afriyati, Mishbahuddin, Habibi. (2021). Layanan Penguasaan Konten Berbasis Digital Game Based Learning Untuk Mengurangi Burnout Belajar. Counsellia: Jurnal Bimbingan dan Konseling, $11(2), 1$ - 14. DOI: 10.25273/counsellia.v11i2.10390

\section{(C) ) EY-NC-SA}

Copyright (C2021 Counsellia: Bimbingan dan Konseling

Published by Universitas PGRI Madiun. This work is licensed under the Creative Commons Attribution-NonCommercialShareAlike 4.0 International License

\section{PENDAHULUAN}

Mahasiswa merupakan sekelompok anak muda yang sedang menuntut ilmu sesuai dengan bidang yang dipilihnya untuk pengembangan diri. Kegiatan mahasiswa sebagai bagian dari peserta didik yaitu belajar, belajar dalam hal ini dapat diartikan belajar tentang materi pendidikan, belajar berperilaku organisasi, belajar tentang sosial masyarakat dan sebagainya guna mencapai kesuksesan. Menurut (Damri et al., 2017) kedudukan mahasiswa yang berperan sebagai seorang yang belajar di tingkat perguruan tinggi akan terus menerus berhubungan dengan tugas-tugas perkuliahan baik secara akademik maupun non akademik. Tugas mahasiswa yang termasuk dalam kategori akademik dapat berupa seperti tugas individu maupun tugas kelompok yang dibebankan oleh dosen pengampu mata kuliah kepada mahasiswa, serta seringkali dalam periode perkuliahan tersebut beban tugas yang diberikan oleh dosen tersebut bisa sampai begitu banyak makalah ataupun paper yang harus secepatnya mahasiswa kerjakan dan selesaikan dengan maksimal, (Rumiani, 2006)

Proses belajar yang optimal merupakan suatu kegiatan yang menghasilkan dampak ataupun efek nyata bagi mahasiswa setiap harinya. Hal ini berarti bahwa materi, informasi perkuliahan yang diberikan dosen bisa digunakan. Mahasiswa dalam proses pencapaian hasil pembelajaran diharapkan mampu menguasai materi, konsep dasar, mampu menjelaskan bahkan mampu menerapkan dan menciptkan kreasi dari proses pembelajaran yang telah diberikan. Mahasiswa dengan segala aktivitasnya sangat beresiko terhadap berbagai macam masalah yang mungkin akan muncul, dalam hal ini salah satu masalah nyata yang sering dialami mahasiswa yaitu kejenuhan belajar atau burnout belajar. Sejalan dengan hal tersebut menurut (Herawati et al., 2020) tuntutan pembelajaran yang semakin besar membuat sebagian besar mahasiswa belum dapat mengkombinasikan berbagai macam cara belajar yang sesuai dengan kebutuhan individu sehingga hal ini mengakibatkan mahasiswa mengalami kejenuhan dalam belajar.

Menurut (Sutarjo et al., 2014) seorang mahasiswa yang mengalami masalah kejenuhan belajar merasa seolah-olah prestasi belajar yang didapatkan tidak ada perkembangan yang signifikan. Mahasiswa yang berada pada kondisi jenuh belajar, sistematika akal dan pikirannya tidak mampu bekerja maksimal, bahkan kejenuhan belajar yang melanda mahasiswa membuat kondisi mereka sulit dikendalikan karena kejenuhan membuat mahasiswa menjadi kehilangan motivasi belajar sehingga berdampak pada minat belajar dan banyak hal lainnya yang ikut terganggu, (Hasan, 2020)

Berdasarkan beberapa uraian sebelumnya, burnout belajar merupakan suatu kondisi keadaan yang lelah atau frustrasi yang dipicu oleh penyimpangan terhadap suatu hal, gaya hidup, ataupun relasi yang gagal menghasilkan tujuan yang diharapkan. Menurut (Tay et al., 2019) burnout dapat diartikan dengan suatau keadaan kelelahan (exhaustion) fisik serta kelelahan emosional yang menimbulkan stres.

Selanjutnya menurut (Maslach, 1993) burnout merupakan suatu bentuk sindrom psikologis yang terbagi menjadi 3 dimensi seperti keletihan atau kelelahan emosional (emotional exhaustion), depersonalization (kelelahan fisik, mental yang terjadi lama dan menunjukkan suatu keanehan), dan menurunnya prestasi diri yang bisa dialami siswa maupun mahasiswa. Berkaitan dengan pendapat sebelumnya, (Dewi \& Yosef, 2017) 
mengemukakan bahwa burnout belajar juga dapat berdampak terhadap afeksi dengan menunjukkan sikap depresi dengan tingkat kecemasan yang sangat tinggi. Sedangkan menurut (Slivar, 2001) burnout merupakan keadaan emosional individu yang merasa letih secara mental dan lelah fisik sebagai dampak tuntutan pekerjaan yang sangat tinggi.

Belandaskan pendapat para ahli sebelumnya maka burnout belajar dapat terjadi karena adanya berbagai macam tekanan dan tuntutan bagi mahasiswa untuk memenuhi segala jenis capaian perkuliahan. Beberapa bentuk burnout belajar yang dialami mahasiswa bermacam-macam, seperti tidak adanya gairah dan semangat untuk mengikuti perkuliahan, enggan mengumpulkan tugas yang diberikan dosen, tidak fokus pada saat perkuliahan berlangsung dan lain sebagainya. Beberapa fenomena burnout belajar dapat dilihat dari hasil penelitian terdahulu seperti menurut (Mianti, 2019) faktor yang membuat kejenuhan belajar dapat dikelompokkan menjadi 3, yaitu kelelahan inderaa mahasiswa, kelelahan fisik yang dialami mahasiswa serta kelelahan mental mahasiswa.

Penelitian yang dilakukan oleh (Sugara, 2011) tentang burnout belajar di SMA Angkasa Bandung yang menunjukkan kejenuhan belajar tinggi sebesar 15,32\% dan kategori sedang $72,97 \%$, hal ini dinilai sangat mengkhawatirkan.

Selanjutnya penelitian burnout belajar oleh (Firmansyah, 2012) di SMPN 1 Lembang dengan hasil yaitu 72,9\% siswa memiliki tingkat kejenuhan belajar kategori sedang. Selanjutnya (Pawicara \& Conilie, 2020) menunjukkan bahwa sebagian besar mahasiswa tadris biologi IAIN Jember menunjukkan gejala kejenuhan belajar dikarenakan kondisi pembelajaran daring yang monoton, hal ini disebabkan oleh faktor eksternal maupun faktor internal mahasiswa. Agar intensitas burnout belajar mahasiswa dapat berkurang, maka perlu adanya tindakan dari peneliti khususnya dalam bidang bimbingan dan konseling, yaitu melalui pemberian suatu layanan BK guna mengurangi kejenuhan belajar atau burnout belajar. Hal ini sejalan dengan pendapat (Aufa, 2014) guru BK maupun Dosen BK perlu melakukan beberapa upaya preventif untuk mengatasi atau mencegah terjadinya burnout belajar, hal ini dapat berupa layanan-layanan yang ada dalam BK. Selanjutnya (Hasanah et al., 2017) menyatakan bahwa penggunaan strategi khusus dalam proses pembelajaran maupun pemberian layanan merupakan pilihan yang tepat supaya kegiatan belajar menjadi lebih maksimal yaitu dengan pemberian layanan penguasaan konten berbasis digital game based learning. (Prayitno, 2012) mengemukakan bahwa "Layanan penguasaan konten (PKO) adalah suatu layanan bantuan yang diberikan kepada seorang individu untuk memiliki kompetensi yang dipelajari melalui kegiatan belajar". (Alfisyahrin, 2019) dalam penelitiannya yang diperoleh hasil bahwa penerapan layanan penguasaan konten terhadap siswa mampu mengurangi tingkat burnout belajar, dan ini dapat dilihat dari hasil penilaian segera dan hasil wawancara yang telah dilakukannya.

Sebagai tindak lanjut fenomena di atas, maka peneliti melakukan modifikasi layanan penguasaan konten untuk mengatasi burnout belajar melalui digital game based learning berbantukan aplikasi kahoot. Menurut (Putri \& Muzakki, 2019) game based learning dapat menjadi pilihan strategi memberikan pengalaman belajar yang asyik dengan sistem kolaborasi antar peserta didik. Digital game based learning adalah salah satu jenis metode pembelajaran dengan bantuan permainan, dengan memanfaatkan aplikasi permainan khusus untuk belajar, (Nida, 2014). Selanjutnya, metode permainan mampu membuat suasana belajar menjadi asyik ataupun menyenangkan, serius namun tetap santai, dengan tetap berada pada rambu-rambu capaian pembelajaran yang telah ditetapkan. Menurut (Arisnawati, 2009) game memiliki pengatuh besar dalam meningkatkan motivasi belajar. Selanjutnya menurut (Rafnis, 2019) permainan sifatnya menyenangkan, membahagiakan serta dapat meningkatkan motivasi bagi si penggunanya, melalui pendekatan permaianan siswa menjadi lebih tinggi rasa keingintahuannya. 
Kebaruan dalam penelitian ini yaitu dengan pemberian layanan penguasaan konten melalui sentuhan perkembangan teknologi yang sangat jarang sekali dilakukan.Penggunaan model game based learning menggunakan aplikasi kahoot yang diberikan melalui layanan penguasaan konten, diharapkan dapat memberikan suasana belajar baru kepada mahasiswa agar mampu secara aktif membangun semangat belajar manditi, mampu menghilangkan kondisi kejenuhan belajar atau burnout belajar dalam kehidupan sehari-hari. Menurut (Mustikawati, 2019) kahoot adalah salah satu game yang sederhana namun mampu memberikan efek senang pada diri siswa, sehingga dapat digunakan dengan sangat mudah untuk bermacam-macam kepentingan pembelajaran yang inovatif. (Irwan et al., 2019) menunjukkan Kahoot merupakan salah satu alternatif solusi media belajar yang interaktif di pendidikan tinggi, hal ini telah dibuktikan melalui penelitian bahwa secara signifikan dapat memberikan efek peningkatan hasil belajar. Berdasarkan beberapa ulasan maka dilakukan penelitian dengan judul "Efektivitas Layanan Penguasaan Konten Berbasis Digital Game Based Learning dengan Aplikasi Kahoot untuk Mengurangi Burnout Belajar Mahasiswa".

\section{METODE PENELITIAN}

Penelitian ini merupakan penelitian kuantitatif dengan metode penelitian eksperimen. Penelitian eksperimen bertujuan untuk mengetahui akibat manipulasi terhadap perilaku individu yang diamati. Kelompok penelitian diberikan perlakuan dengan layanan penguasaan konten berbasis digital game based learning dengan aplikasi kahoot, hanya menyelesaikan tes awal (pretest) dan tes akhir (posttest). Variabel bebas penelitian ini adalah layanan penguasaan konten berbasis digital game based learning dengan aplikasi kahoot. Sedangkan, variabel terikat adalah burnout belajar mahasiswa. Diagram rancangan penelitian ini dapat dilihat pada Gambar 2

\begin{tabular}{lllll}
\hline $\mathrm{E}$ & $:$ & $\mathrm{O}_{1}$ & $\mathrm{X}$ & $\mathrm{O}_{2}$
\end{tabular}

Gambar 1: Rancangan Penelitian The Non Equivalent Control Group

Keterangan :

E : Kelompok eksperimen

$\mathrm{O}_{1} \quad$ : Eksperimen pretest

$\mathrm{O}_{2} \quad$ : Eksperimen posttest

$\mathrm{X}$ : Layanan penguasaan konten berbasis digital game based learning dengan aplikasi kahoot.

Materi yang disampaikan terdiri dari lima tema penguasaan konten yang berbasis teknologi informasi, selanjutnya setiap akhir sesi pertemuan diberikan quis yang menarik yang sesuai dengan materi yang telah diberikan.

\section{Rancangan Penelitian}

Prosedur penelitian ini memiliki beberapa tahapan yaitu: 1) tes awal (pretest); 2) setelah pretest diberikan, mahasiswa selanjutnya diberikan treatment berupa layanan penguasaan konten berbasis digital game based learning menggunakan aplikasi kahoot sebanyak 5 kali pertemuan yaitu meliputi pertemuan pertama membahas materi teknologi Informasi dalam layanan orientasi dan informasi; materi kedua yaitu TI sebagai media bimbingan belajar; materi ketiga yaitu TI untuk layanan bimbingan klasikal; materi keempat TI untuk assessment; dan materi kelima yaitu TI untul layanan penempatan dan penyaluran; 3) setelah pelaksanaan treatment selesai, mahasiswa diberikan post test. Penelitian ini dilakukan selama 3 bulan dengan pemberian treatment sebanyak 5 kali serta 
pemberian pre-test dan post-test. Pemberian treatment layanan penguasaan konten berbasis digital game based learning dengan aplikasi kahoot dilakukan oleh 3 orang dosen Bimbingan dan Konseling Universitas Bengkulu selaku peneliti.

\section{Sumber Data}

Jumlah partisipan yang terlibat dalam penelitian ini yaitu 37 dengan jumlah populasi sebesar 80 Mahasiswa Program studi Bimbingan dan Konseling Universitas Bengkulu. Sampel diambil melalui teknik purposive sampling, yaitu mahasiswa yang mengalami burnout belajar selama perkuliahan. Kegiatan ini diberikan dengan menggunakan format layanan klasikal

\section{Teknik Pengumpulan Data}

Instrumen yang digunakan pada penelitian ini adalah kuesioner burnout belajar dalam bentuk pertanyaan tertutup berskala likert. Pilihan jawaban yang dibuat yaitu Sangat Sesuai (SS) bernilai 5, Sesuai (S) bernilai 4, Cukup (C) bernilai 3, Kurang Sesuai (KS) bernilai 2, dan Tidak Sesuai (TS) bernilai 1. Aspek-aspek yang diukur dalam burnout belajar menggunakan teori dari Maslach \& Leiter yaitu: keletihan emosi (emotional exhaustion), Depersonalisasi/Sinisme (cynism), dan menurunnya keyakinan akademik (reduce academic efficacy).

Uji validitas dan realibillitas dilakukan pada 30 mahasiswa Bimbingan dan Konseling UNIB semester 1 dengan 35 item pernyataan. Pengambilan keputusan untuk menentukan valid atau tidak validnya item pernyataan dilakukan dengan membandingkan signifikansi korelasi dengan 0,05 dan bernilai positif. Bila signifikansi $<0,05$ dan juga bernilai positif maka item pernyataan dinyatakan valid, dan sebaliknya bila signifikansi > 0,05 dan bernilai negatif maka item pernyataan dinyatakan tidak valid. Hasil uji validias diperoleh 30 item pernyataan yang valid. Hasil uji reliabilitas menunjukkan nilai alpha chronbach sebesar 0,835. Hasil ini menunjukkan 30 item burnout belajar dinyatakan reliabel.

\section{Teknik Analisis Data}

(Yusuf, 2013) menyebutkan bahwa analisis data adalah langkah yang harus dilakukan dalam penelitian yang bertujuan untuk menentukan ketepatan hasil penelitian. Penelitian ini menggunakan statistic compare means dengan menggunakan rumus paired sample t-tes setelah uji prasyarat normalitas terpenuhi. Pengambilan keputusan hipotesis diterima atau ditolak adalah dengan ketentuan nilai sig. (2-tailed) $<0.05 \mathrm{maka}_{\mathrm{o}}$ ditolak, artinya layanan penguasaan konten berbasis digital game based learning dengan aplikasi kahoot berpengaruh atau memiliki efektifitas dalam mengurangi burnout belajar mahasiswa.

\section{HASIL DAN PEMBAHASAN}

\section{Hasil}

\section{a. Hasil Data Burnout Belajar Mahasiswa Sebelum Diberikan Perlakuan}

Berikut ini skor masing-masing tingkat burnout belajar mahasiswa sebelum diberikan perlakuan dapat dilihat pada tabel 1 berikut: 
Tabel 1. Hasil Pretest Tingkat Burnout Belajar Mahasiswa BK

\begin{tabular}{cccc}
\hline Interval & Kategori & \multicolumn{2}{c}{ Pretest } \\
\hline$>146$ & Sangat Tinggi & Frekuensi & $\%$ \\
$133-145$ & Tinggi & 15 & 21,62 \\
$120-132$ & Sedang & 10 & 40,54 \\
$94-119$ & Rendah & 2 & 27,02 \\
$<93$ & Sangat Rendah & 2 & 5,41 \\
& Jumlah & 37 & 5,41 \\
\hline
\end{tabular}

Berdasarkan tabel di atas, tingkat burnout belajar mahasiswa paling dominan berada pada kategori tinggi dengan jumlah frekuensi sebesar 15 dan nilai persentase sebesar 40,54\%. Hal ini menunjukkan bahwa kondisi mahasiswa mengalami kondisi burnout belajar mulai dari sedang bahkan sampai dengan kategori sangat tinggi.

\section{b. Hasil Data Burnout Belajar Mahasiswa Setelah Diberikan Perlakuan}

Berikut ini skor masing-masing tingkat burnout belajar mahasiswa setelah diberikan perlakuan dapat dilihat pada tabel 2 berikut:

Tabel 2. Hasil Postest Tingkat Burnout Belajar Mahasiswa BK

\begin{tabular}{cccc}
\hline Interval & Kategori & \multicolumn{2}{c}{ Postest } \\
\hline$>146$ & Sangat Tinggi & 1 & Frekuensi \\
\hline $133-145$ & Tinggi & 4 & 2,70 \\
$120-132$ & Sedang & 14 & 10,81 \\
$94-119$ & Rendah & 17 & 37,84 \\
$<93$ & Sangat Rendah & 1 & 45,95 \\
& Jumlah & 37 & 2,70 \\
\hline
\end{tabular}

Berdasarkan tabel di atas, tingkat burnout belajar mahasiswa setelah mendapat perlakuan layanan penguasaan konten berbasis digital game based learning dengan aplikasi kahoot. Mahasiswa diketahui setelah melakukan postest mengalami perubahan tingkat burnout belajar menjadi kearah yang lebih rendah dari sebelumnya, hal ini dikarenakan telah diberikan layanan penguasaan konten berbasis digital game based learning dengan aplikasi kahoot sehingga mahasiswa yang awalnya jenuh menjadi lebih bersemangat dalam belajar. Hal ini terlihat dari antusias dan kebahagiaan mahasiswa mengikuti kuis materi dengan metode bermain dengan aplikasi kahoot.

\section{c. Hasil Data Perbedaan Burnout Belajar Mahasiswa Sebelum dan Setelah Diberikan Perlakuan}

Berikut ini skor tingkat burnout belajar mahasiswa sebelum dan sesudah diberikan perlakuan pada Tabel 3. 
Tabel 3. Perbandingan Hasil Pretest dan Posttest Burnout Belajar Mahasiswa BK kelas 1B Tahun Ajaran 2020/2021

\begin{tabular}{cccccc}
\hline \multirow{2}{*}{ Interval } & \multirow{2}{*}{ Kategori } & \multicolumn{2}{c}{ Pretest } & \multicolumn{2}{c}{ Posttest } \\
& Frekuensi & \% & Frekuensi & \% \\
\hline$>146$ & Sangat Tinggi & 8 & 21,62 & 1 & 2,70 \\
$133-145$ & Tinggi & 15 & 40,54 & 4 & 10,81 \\
$120-132$ & Sedang & 10 & 27,02 & 14 & 37,84 \\
$94-119$ & Rendah & 2 & 5,41 & 17 & 45,95 \\
$<93$ & Sangat Rendah & 2 & 5,41 & 1 & 2,70 \\
\hline Jumlah & & 37 & 100 & 37 & 100 \\
\hline
\end{tabular}

Berdasarkan tabel di atas, dapat dijelaskan bahwa terdapat perbedaan tingkat burnout belajar mahasiswa sebelum dan sesudah mendapat perlakuan layanan penguasaan konten berbasis digital game based learning dengan aplikasi kahoot. Dapat dilihat dari hasil posttest sebanyak 1 orang mahasiswaa berada pada kategori sangat tinggi $(2,70 \%)$, dan secara keseluruhan mahasiswa berada pada kategori sedang dan rendah.

Berdasarkan uraian data di atas, diperoleh hasil bahwa terdapat perbedaan tingkat burnout belajar mahasiswa setelah diberi layanan penguasaan konten berbasis digital game based learning dengan aplikasi kahoot. Selanjutnya untuk mengetahui hasil uji hipotesis penelitian maka dapat dilihat pada tabel di bawah ini.

Tabel 4. Paired Sample Test

\begin{tabular}{|c|c|c|c|c|c|c|c|c|c|}
\hline \multicolumn{10}{|c|}{$\begin{array}{l}\text { Paired Sample Test } \\
\text { Paired Differences }\end{array}$} \\
\hline & & \multirow[t]{4}{*}{ Mean } & \multirow{4}{*}{$\begin{array}{l}\text { Std. } \\
\text { Deviat } \\
\text { ion }\end{array}$} & \multirow{4}{*}{$\begin{array}{l}\text { Std. } \\
\text { Error } \\
\text { Mean }\end{array}$} & \multicolumn{2}{|l|}{$95 \%$} & \multirow{4}{*}{$\mathrm{T}$} & & \multirow{4}{*}{$\begin{array}{l}\text { Sig. } \\
(2- \\
\text { taulec } \\
)\end{array}$} \\
\hline & & & & & \multirow{2}{*}{\multicolumn{2}{|c|}{$\begin{array}{l}\text { Confidence } \\
\text { Internal of the } \\
\text { Difference }\end{array}$}} & & & \\
\hline & & & & & & & & $\mathrm{df}$ & \\
\hline & & & & & Lower & Upper & & & \\
\hline Pai & Pretes & 34.177 & 6.921 & 2.843 & 24.95 & 40.421 & 11.520 & & .000 \\
\hline r I & & & & & 2 & & 5 & & \\
\hline & Postte & & & & & & & & \\
\hline
\end{tabular}

Berdasarkan hasil perhitungan pada tabel 4 dapat dilihat bahwa nilai sig.(2tailed) aalah .000 yang berarti bahwa nilai signifikasi $0.000<0.05$ sehingga Ho ditolak dan $\mathrm{Ha}$ diterima. Hal ini berarti bahwa layanan penguasaan konten berbasis digital game based learning dengan aplikasi kahoot efektif dalam mengurangi burnout belajar mahasiswa.

\section{Pembahasan}

Hasil penelitian ini yaitu menunjukkan bahwa layanan penguasaan konten berbasis digital game based learning dengan aplikasi kahoot terbukti efektif dalam mengurangi tingkat burnout belajar. Kondisi burnout belajar mahasiswa merupakan suatu bentuk dari kejenuhan atas rutinitas belajar secara terus-menerus, hal ini bisa disebabkan oleh penggunaan media belajar yang cenderung monoton, tidak bervariasi sehingga mahasiswa merasa bosan. Melalui pemberian layanan penguasaan konten berbasis digital game based learning dengan aplikasi kahoot merupakan langkah yang dapat diambil oleh peneliti untuk melihat perubahan kondisi burnout belajar mahasiswa. Seperti hasil penelitian yang dilakukan oleh (Alfisyahrin, 2019) tentang layanan penguasaan konten 
yang terbukti mampu mengurangi tingkat burnout belajar siswa, siswa sudah mampu menangani masalah burnout belajar yang bisa dilihat dari kemampuan berfikirs serta perilaku siswa dalam upaya mengatasi burnout belajar.

Selanjutnya, penelitian terdahulu yang dilakukan oleh (Wibawa et al., 2021) tentang penggunaan game based learning sebagai inovasi dan solusi percepatan belajar mahasiswa, hasil yang diperoleh yaitu melalui game based learning ini dapat mengaktifkan proses belajar mengajar serta sangat direkomendasikan untuk dapat digunakan oleh para pengajar ataupun peneliti berikutnya. Berdasarkan penelitian terdahulu, peneliti melakukan layanan penguasaan konten berbasis digital game based learning dengan aplikasi kahoot memberikan hasil bahwa terdapat perubahan tingkat burnout belajar mahasiswa setelah diberikan layanan, hal ini diperoleh dari hasil penilaian segera pada proses penelitian menunjukan bahwa mahasiswa menjadi lebih aktif dan semangat mengikuti kegiatan pembelajaran dengan mengisi kuis yang diberikan melalui aplikasi kahoot.

Hal ini sesuai dengan yang disampaikan oleh (Nurwanto et al., 2020) game based learning merupakan cara atau metode belajar yang menyuguhkan pengalaman belajar yang menstimulus keikutsertaan siswa dalam proses pembelajaran. Berdasarkan analisis data, dapat ditarik kesimpulan layanan penguasaan konten berbasis digital game based learning dengan aplikasi kahoot lebih efektif mengurangi tingkat burnout belajar mahasiswa. Dengan begitu kemampuan dosen ataupun pendidik pada umumnya dalam memilih metode belajar yang menarik mampu meningkatkan motivasi belajar, mampu menghilangkan kejenuhan belajar. (Bunyamin et al., n.d.) menyebutkan bahwa media kahoot di gunakan sebagai variasi dalam kegiatan belajar mengajar, karena siswa butuh suasana belajar yang tidak monoton, asik, menarik.

Selanjutnya (Fauzan et al., 2020) menunjukkan bahwa jika menggunakan media Kahoot suasana belajar menjadi menyenangkan dan menarik dan juga tercipta komunikasi dua arah dari pendidik kepada mahasiswa ataupun sebaliknya. Menurut (Ridwan \& Sari, 2020) peran guru ataupun dosen dalam merancang pembelajaran yang kreatif sangat terhadap tingkat kejenuhan belajar mahasiswa, semakin menarik model pembelajaran yang diberikan oleh guru maka tingkat kejenuhan belajar mahasiswa semakin rendah.

Berdasarkan beberapa uraian di atas, hasil penelitian menunjukkan penggunaan layanan penguasaan konten berbasis digital game based learning dengan aplikasi kahoot efektif untuk mengurangi burnout belajar mahasiswa. Adapun keterbatasan penelitian ini yaitu hanya dilakukan pada mahasiswa bimbingan dan konseling semester 4 Universitas Bengkulu, serta menggunakan One-Group Pretest-Posttest Design tanpa kelas kontrol. Hal ini dapat menjadi bahan masukan untuk penelitian selanjutnya agar dapat mengkaji dengan teknik penelitian yang lain. Sampel penelitian terbatas sehingga tidak dapat digeneralisasikan.

\section{SIMPULAN}

Kesimpulan yang didapatkan pada penelitian ini yaitu layanan penguasaan konten berbasis digital game based learning dengan aplikasi kahoot efektif mengurangi tingkat burnout belajar mahasiswa. Sesuai dengan hasil temuan penelitian tersebut peneliti merekomendasikan kepada Dosen program studi Bimbingan dan Konseling khususnya di Universitas Bengkulu untuk menerapkan pembelajaran dengan digital game based learning, selanjutnya hal ini juga dapat diterapkan oleh Guru Bimbingan dan Konseling di sekolah dengan memberikan inovasi pada setiap layanan dengan mengaplikasikan digital game based learning dengan aplikasi kahoot guna menarik perhatian peserta didik. 


\section{UCAPAN TERIMAKASIH}

Penulis mengucapkan banyak terimakasih kepada ketua LPPM, Dekan FKIP dan Ka. Prodi Bimbingan dan Konseling Universitas Bengkulu atas dukungan yang diberikan kepada peneliti dalam menyelesaikan penelitian ini.

\section{DAFTAR PUSTAKA}

Alfisyahrin, H. (2019). Penerapan Layanan Penguasaan Konten untuk Mengatasi Burnout Belajar Siswa Kelas X SMA Harapan Mekar Medan Tahun Pembelajaran 2018/2019.

Arisnawati, D. (2009). Penggunaan Metode Bermain Benda-benda Konkret dalam Peningkatan Keterampilan Hitungan Dasar Kelas III Sekolah Dasar Negri 1 Kebumen. UNS.

Aufa, A. (2014). Upaya Preventif Guru Bimbingan dan Konseling Terhadap Terjadinya Burnout. Hisbah: Jurnal Bimbingan Konseling Dan Dakwah Islam, 11(1), 1-14.https://doi.org/10.14421/hisbah.2014.11101

Bunyamin, A. C., Juita, D. R., \& Syalsiah, N. (n.d.). Penggunaan Kahoot Sebagai Media Pembelajaran Berbasis Permaianan Sebagai Bentuk Variasi Pembelajaran. Gunahumas, 3(1), 4350.https://ejournal.upi.edu/index.php/gunahumas/article/view/28388/1 2856

Damri, D., Engkizar, E., \& Anwar, F. (2017). Hubungan Self-Efficacy Dan Prokrastinasi Akademik Mahasiswa Dalam Menyelesaikan Tugas Perkuliahan. JURNAL EDUKASI: Jurnal Bimbingan Konseling, 3(1), 74-95. http://dx.doi.org/10.22373/je.v3i1.1415

Dewi, R. P., \& Yosef, H. (2017). Hubungan antara Academic Self-Confidence dengan Kejenuhan (Burnout) Belajar Siswa SMK Negeri 1 Indralaya Utara. Konseling Komprehensif, 4(2), 14-27. https://core.ac.uk/download/pdf/267824937.pdf

Fauzan, A., Safira, M. C., \& Sulistyo, E. N. (2020). Inisiasi Kahoot! sebagai variasi pembelajaran kalkulus bagi mahasiswa teknik lingkungan. Jurnal Riset Pendidikan Matematika, 7(1). https://doi.org/10.21831/jrpm.v7i1.33735

Firmansyah, R. (2012). Efektivitas Teknik Self Instruction Untuk Mereduksi Gejala Kejenuhan Belajar Siswa. Skripsi Jurusan Psikologi Pendidikan Dan Bimbingan UPI. http://repository.upi.edu/62650/

Hasan, M. S. (2020). Implikasi Kejenuhan (Burnout) Belajar Terhadap Minat Belajar Peserta Didik pada Mata Pelajaran Pendidikan Agama Islam Di SMP Negeri 2 Diwek Jombang. Al Hikmah: Jurnal Studi Keislaman, 10(1), 105-116. http://ejournal.kopertais4.or.id/pantura/index.php/alhikmah/article/vie w/3493

Hasanah, U., Ahmad, R., \& Karneli, Y. (2017). Efektivitas Layanan Penguasaan Konten untuk Meningkatkan Konsentrasi Belajar Siswa. 
http://repository.unp.ac.id/id/eprint/11244

Herawati, A. A., Afriyati, V., Habibah, S., \& Pratiwi, C. (2020). Efektifitas Penggunaan Media Pembelajaran Berbasis Blended Learning untuk Mengurangi Burnout Belajar Pada Perkuliahan Bimbingan dan Konseling Keluarga di Prodi Bimbingan dan Konseling Universitas Bengkulu. Educational Guidance and Counseling Development Journal, 3(2), 40-48. http://dx.doi.org/10.24014/egcdj.v3i2.10784

Irwan, I., Luthfi, Z. F., \& Waldi, A. (2019). Efektifitas Penggunaan Kahoot! untuk meningkatkan hasil belajar siswa [Effectiveness of using Kahoot! to improve student learning outcomes]. PEDAGOGIA: Jurnal Pendidikan, 8(1), 95104.https://doi.org/10.21070/pedagogia.v8i1.1866 Maslach. (1993). Burnout, a multidimensional perspective. In: Schaufeli W, Maslach C, Merek T, eds. Professional Burnout: Recent Development in Theory And Research. Taylor \& Francis.

Mianti, R. (2019). Penggunaan Rational Emotive Behavioral Therapy Untuk Menurunkan Burnout Belajar Pada Siswa Kelas XI Di SMA Negeri 1 Bangun Purba. Universitas Islam Negeri Sumatera Utara. https://core.ac.uk/reader/268997790

Mustikawati, F. E. (2019). Fungsi Aplikasi Kahoot sebagai Media Pembelajaran Bahasa Indonesia. Seminar Nasional Pendidikan Bahasa Dan Sastra, 99-104.

https://ejournal.unib.ac.id/index.php/semiba/article/view/10281

Nida. (2014). Digital Game-Based Learning.

Http://Komunikasi.Im.Ac.Id/2014/12/Digital-Game-Based-Learning. https://doi.org/10.1145/950566.950596

Nurwanto, N., Islahul, M., Ida Ayu Hani, E., Nikmah Sistia Eka, P., \& Dwi, S. (2020). Gamifikasi Interaktif Dalam Pembelajaran Bahasa Inggris Menggunakan Strategi VGER (Visualization, Game, Evaluation, Repetition). http://eprints.uad.ac.id/16333/1/Kelompok 1 Haki.pdf

Pawicara, R., \& Conilie, M. (2020). Analisis Pembelajaran Daring Terhadap Kejenuhan Belajar Mahasiswa Tadris Biologi Iain Jember di Tengah Pandemi Covid-19. ALVEOLI: Jurnal Pendidikan Biologi, 1(1), 2938. https://doi.org/10.35719/alveoli.v1i1.7

Prayitno. (2012). Seri Panduan Layanan dan Kegiatan Pendukung Konseling. UNP Press.

Putri, A. R., \& Muzakki, M. A. (2019). Implemetasi Kahoot Sebagai Media Pembelajaran Berbasis Digital Game Based Learning Dalam Mengahadapi Era Revolusi Industri 4.0. Prosiding Seminar Nasional Universitas Muria Kudus, 1-7. https://pgsd.umk.ac.id/files/prosiding/2019/27_Aprilia_Riyana.pdf

Rafnis, R. (2019). Pemanfaatan Platform Kahoot Sebagai Media Pembelajaran Interaktif. E-Tech: Jurnal Ilmiah Teknologi Pendidikan, 6(2). https://doi.org/10.24036/et.v2i2.101336

Ridwan, I. Q., \& Sari, D. A. (2020). Peran Guru dalam Membuat Model Pembelajaran Daring yang Inovatif dan Kreatif. Prosiding Seminar 
Nasional Penelitian LPPM UMJ, I(1). https://jurnal.umj.ac.id/index.php/semnaslit/article/view/8787

Rumiani, R. (2006). Prokrastinasi Akademik Ditinjau dari Motivasi Berprestasi dan Stres Mahasiswa. Jurnal Psikologi Undip, 3(2), 128210. https://www.neliti.com/publications/128210/prokrastinasi-akademikditinjau-dari-motivasi-berprestasi-dan-stres-mahasiswa

Slivar, B. (2001). The syndrome of burnout, self-image, and anxiety with grammar school students. Horizons of Psychology, 10(2), 21-32. http://psiholoska-obzorja.si/arhiv_clanki/2001_2/slivar.pdf

Sugara, G. S. (2011). Efektivitas Teknik Self Instruction dalam Menangani Kejenuhan Belajar Siswa. Skripsi Jurusan PPBFIP UPI. Bandung: FIP UPI. http://repository.upi.edu/62441/

Sutarjo, I. P. E., Putri, D. A. W. M., \& Suarni, N. K. (2014). Efektivitas Teori Behavioral Teknik Relaksasi Dan Brain Gym Untuk Menurunkan Burnout Belajar Pada Siswa Kelas Viii Smp Laboratorium Undiksha Singaraja Tahun Pelajaran 2013/2014. Jurnal Jurusan Bimbingan Konseling Undiksha, 2(1). http://dx.doi.org/10.23887/jibk.v2i1.3740

Tay, E. D., Trishinta, S. M., \& Candrawati, E. (2019). Burnout Full Day School dengan Tingkat Stres pada Siswa Kelas X Di SMAK FRATERAN MALANG. Nursing News: Jurnal Ilmiah Keperawatan, 4(2). https://doi.org/10.33366/nn.v4i2.2014

Wibawa, A. C. P., Mumtaziah, H. Q., Sholaihah, L. A., \& Hikmawan, R. (2021). Inovasi Game-Based Learning sebagai Solusi Percepatan Adaptasi Belajar Masa New Normal. INTEGRATED (Journal of Information Technology and Vocational Education), 3(1), 17-22. https://ejournal.upi.edu/index.php/integrated/article/view/32729

Yusuf, A. M. (2013).

MetodePenelitianKualitatif,KuantitatifdanPenelitianGabungan (Pertama). Renika Cipta.

\section{PROFIL SINGKAT}

Anna Ayu Herawati adalah Dosen Program Studi Bimbingan dan Konseling, Fakultas Keguruan dan Ilmu Pendidikan, Universitas Bengkulu. Ia juga merupakan editor dari jurnal Consilia. Selain itu ia aktif dalam projek penelitian pada pengembangan media BK.

Vira Afriyati adalah Dosen Program Studi Bimbingan dan Konseling, Fakultas Keguruan dan Ilmu Pendidikan, Universitas Bengkulu. Ia juga merupakan editor dari jurnal Consilia. Selain itu ia aktif dalam projek penelitian pada pengembangan media BK.

Arsyadani Mishbahuddin adalah Dosen Program Studi Bimbingan dan Konseling, Fakultas Keguruan dan Ilmu Pendidikan, Universitas Bengkulu. Ia aktif dalam projek penelitian pada pengembangan media BK.

Ahmad Syaf Ya Habibi adalah alumni mahasiswa Program Studi Bimbingan dan Konseling Universitas Negeri Padang 